\title{
PERANCANGAN MEKANIKA DAN PENGEREMAN PLUGGING MOTOR ARUS SEARAH PADA PROTOTYPE OVERHEAD CRANE BERBASIS PLC
}

\author{
Arsyad Sila Rahmana*), Tejo Sukmadi, dan Mochammad Facta \\ Departemen Teknik Elektro, Universitas Diponegoro \\ Jl. Prof. Sudharto, SH, Kampus UNDIP Tembalang, Semarang 50275, Indonesia \\ ${ }^{*}$ E-mail : arsyadsilarahmana@ gmail.com
}

\begin{abstract}
Abstrak
Pertumbuhan dan perkembangan industri saat ini semakin meningkat seiring meningkatnya kebutuhan manusia. Untuk meningkatkan produksi dan memudahkan pendistribusian produk, alat pemindah atau yang biasa disebut crane diperlukan. Motor arus searah adalah salah satu jenis motor yang digunakan sebagai penggerak crane. Namun, ada banyak kontrol crane menggunakan kontak relay atau kontaktor. Hal ini membuat sulit dalam pemantauan, pengkabelan yang rumit, dan membutuhkan relay timer tambahan untuk mengatur waktu pengereman. Penggunaan Programable Logic Control (PLC) dapat mengatasi hambatan tersebut. PLC dirancang untuk mengendalikan pergerakan dan pengereman dengan metode plugging. Berdasarkan hasil pengujian, PLC telah berhasil mengendalikan pergerakan dan pengereman pada motor arus searah magnet permanen tipe CSD80A1-A. Tegangan masukan motor dapat divariasikan dengan menggunakan penyearah gelombang penuh terkontrol penuh untuk suplai motor hoisting dan buck converter untuk suplai motor longitudinal dan transversal kondisi tanpa beban dan berbeban. Dalam riset ini, mekanisme plugging dikendalikan oleh PLC digunakan untuk pengereman. Berdasarkan pengujian ditemukan bahwa semakin besar tegangan suplai motor, maka arus pengereman motor juga semakin besar pada rentang 2,4 A sampai 5,2 A pada kondisi beban 5 $\mathrm{Kg}$.
\end{abstract}

Kata kunci: PLC, pengereman plugging, prototype overhead crane, motor arus searah magnet permanen CSD80A1-A.

\begin{abstract}
Development of the industry today is increasing as human needs increased. To improve the production and to facilitate the distribution of products, a transfer tool or commonly called a crane is required. Direct current motor is one type of motor used as a crane drive. However, there are a lot of crane control using relay contacts or contactors. These contactors makes difficult in monitoring, have complicated wiring, and need additional timer relays for braking. The use of Programable Logic Control (PLC) can overcome these obstacles. PLC is designed to control movement and braking using plugging method. Based on the test results, PLC has succesfully controled the movement and braking plugging direct current motor CSD80A1-A. The motor input voltage can be varied by using a fully controlled full-wave rectifier for hoisting motor supply and buck converter for longitudinal and transversal motor supplies under no load and loaded condition. In this work, plugging mechanism controlled by PLC has been applied for motor braking.. It is found that the greater motor supply voltage, then the motor braking current is also getting bigger in the rate of 2,4 A to 5,2 A $5 \mathrm{Kgs}$ to up for load.
\end{abstract}

Keywords: PLC, plugging braking, prototype overhead crane, permanent magnetic direct current motor CSD80A1-A.

\section{Pendahuluan}

Pertumbuhan dan perkembangan industri dewasa ini meningkat seiring dengan meningkatnya kebutuhan manusia. Untuk menyeimbangkan produksi yang dihasilkan sesuai dengan permintaan konsumen maka pihak industri dituntut untuk meningkatkan hasil produksi serta untuk memperlancar pendistribusian produknya baik itu dengan kapasitas kecil maupun dengan kapasitas yang besar. Didalam pendistribusian produk yang berkapasitas besar diperlukan sebuah alat pemindah (pesawat angkat) atau yang biasa disebut crane untuk memperlancar kegiatan produksi disuatu industri yang sangat tidak mungkin diangkat oleh manusia[1].

Crane merupakan alat angkat yang memiliki kemampuan untuk memindahkan material/benda secara vertical maupun horizontal. Pada crane terdapat hoist yang berfungsi untuk menciptakan keunggulan mekanis 
sehingga dapat memindahkan beban diluar kemampuan manusia[1].

Crane bergerak dengan menggunakan mesin. Salah satu mesin yang digunakan adalah motor arus searah magnet permanen. Motor ini merupakan mesin listrik yang mengubah energi listrik arus searah menjadi energi mekanis. Motor arus searah sering digunakan di bidang industri seperti crane, conveyor, lift, dan lain sebagainya[2][3]. Pada Penelitian ini menggunakan motor arus searah magnet permanen tipe CSD80A1-A.

Crane harus memiliki ketepatan posisi ketika berhenti, oleh karena itu pada Penelitian ini menggunakan metode pengereman plugging karena motor arus searah magnet permanen dapat dihentikan dengan cepat menggunakan metode plugging.

Dengan menggunakan PLC sistem pada crane menjadi lebih sederhana, tidak membutuhkan banyak perangkat pendukung dan mudah dimodifikasi dibanding sistem kendali menggunakan relay kontak yang kurang efektif[4][5][6][7]. Pada Penelitian ini PLC yang digunakan adalah SYMAC CQM1 CPU-21 yang merupakan produk Omron, digunakan sebagai pengatur koordinasi antara proses mekanika gerakan dan pengereman motor arus searah untuk mempercepat kondisi diam motor arus searah magnet permanen saat prototype overhead crane selesai digunakan[8].

\section{Metode}

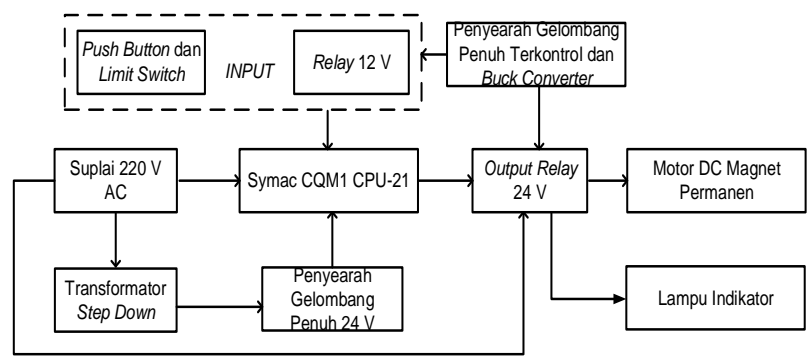

Gambar 1. Blok diagram perancangan

Gambar 1 menunjukkan blok diagaram perancangan dimana sumber tegangan AC satu fase menjadi sumber utama pada rangkaian. Transformator CT digunakan untuk menurunkan tegangan dari 220 volt ke 18 volt sebagai sumber penyearah gelombang penuh 24 volt.

Pada PLC dibuat program deteksi kegagalan penyearah gelombang penuh terkontrol penuh dan buck converter, mekanika gerakan prototype overhead crane, dan pengereman motor arus searah CSD80A1-A.

Inputan PLC merupakan push button, limit switch dan relay 12 volt. Relay 12 volt digunakan sebagai pendeteksi ada tidaknya tegangan keluaran dari penyearah gelombang penuh terkontrol penuh dan buck converter. Jika ada tegangan keluaran penyearah gelombang penuh terkontrol penuh dan buck converter dan dapat mengaktifkan relay 12 volt, maka PLC mendeteksinya sebagai input yang menandakan bahwa penyearah gelombang penuh terkontrol penuh dan buck converter bekerja dengan baik. Output PLC adalah relay 24 volt yang berfungsi untuk menghubungkan penyearah gelombang penuh terkontrol penuh dan buck converter dengan motor arus searah magnet permanen CSD80A1-A.

\subsection{Perancangan Program}

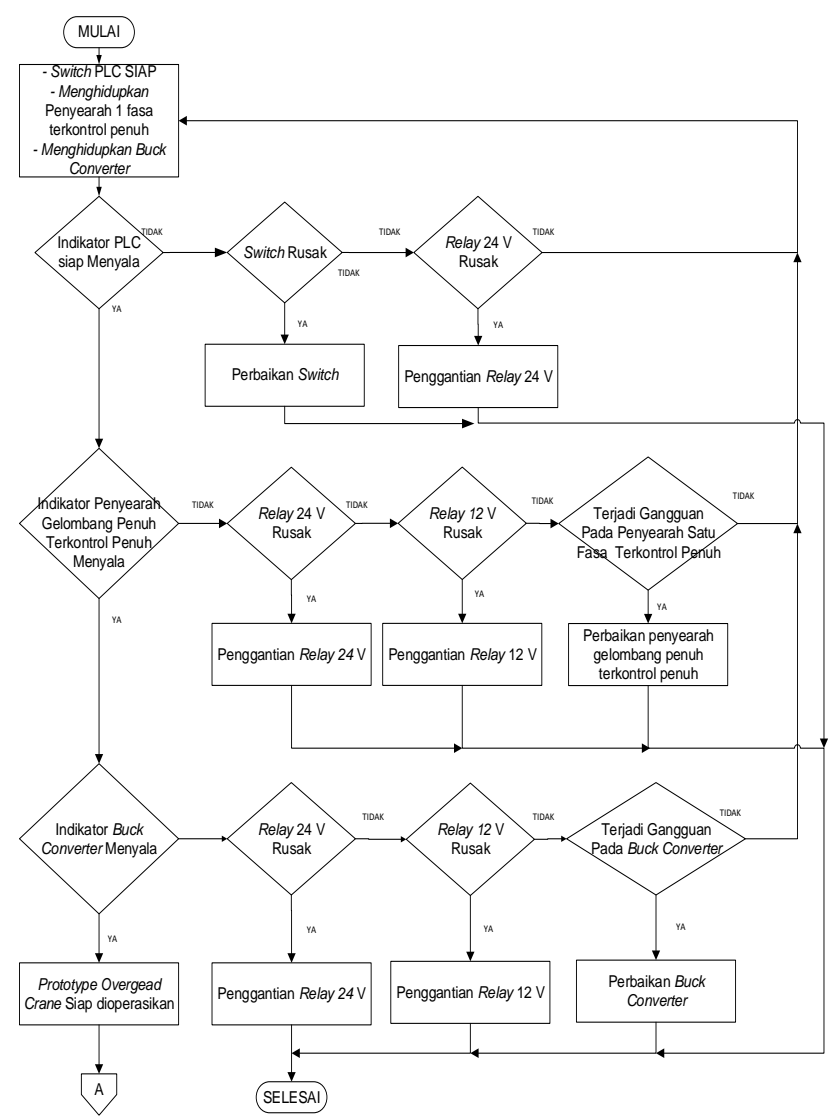

Gambar 2. Diagram alir deteksi kegagalan penyearah satu fasa terkontrol penuh dan buck converter

Berdasarkan Gambar 2 diagram alir deteksi kegagalan penyearah satu fasa terkontrol penuh dan buck converter, prototype overhead crane siap dioperasikan apabila indikator PLC, penyearah gelombang penuh terkontrol penuh, dan buck converter menyala. Apabila indikator prototype overhead crane siap tidak menyala kemungkinan terjadi kerusakan pada switch PLC siap atau terjadi kegagalan penyearah gelombang penuh terkontrol penuh atau buck converter, oleh sebab itu dilakukan pengecekan pada switch, relay 24 volt dan relay 12 volt, apabila tidak terjadi kerusakan pada switch, relay 24 volt, dan relay 12 volt maka dapat disimpulkan ada kerusakan pada penyearah gelombang penuh 
terkontrol penuh atau buck converter.kerusakan pada switch oleh karena itu dilakukan penggantian switch.

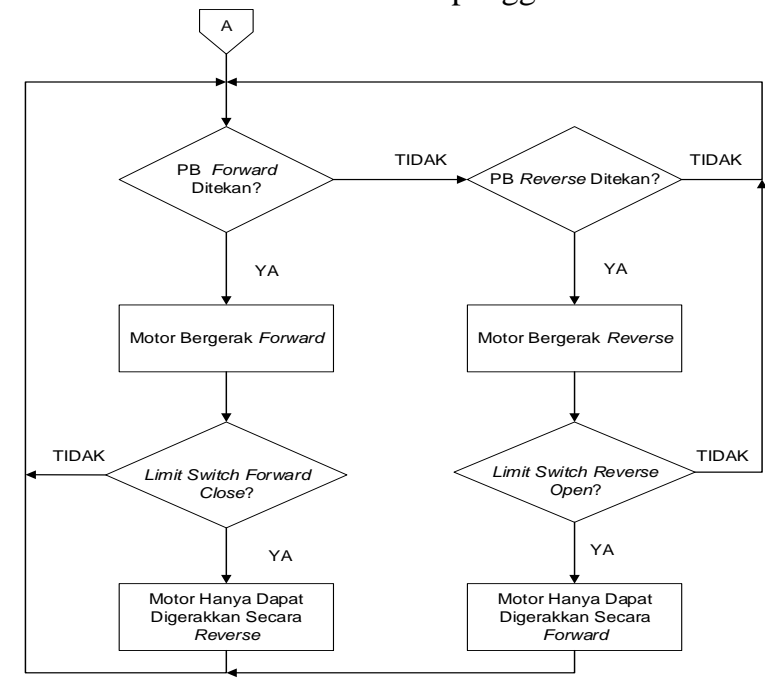

Gambar 3. Diagram alir gerakan Overhead Crane

Pada diagram alir gerakan Gambar 3 tersebut ketika push button forward ditekan maka motor transversal akan bergerak forward sampai limit switch forward dalam keadaan close (tertekan) maka motor akan berhenti dan hanya bisa digerakkan secara reverse sampai limit switch kembali dalam keadaan open. Hal tersebut juga berlaku pada gerakan reverse. Ketika push button kembali dalam keadaan open maka sistem akan kembali dalam keadaan stand by. Diagram alir gambar 3 berlaku pada semua mode gerakan baik longitudinal, transversal, maupun hoisting. Tetapi, pada mode gerakan hoisting tidak terdapat limit switch untuk gerakan reverse, karena gerakan reverse pada mode hoisting adalah gerakan menurunkan beban, sehingga tidak membutuhkan limit switch.

\subsection{Perancangan Sumber Tegangan Searah 24 Volt}

Perancangan penyearah gelombang penuh satu fase dengan center tap ini digunakan sebagai sumber tegangan input dan output PLC. Trafo center tap dipilih karena lebih banyak pilihan tap tegangannya dan hanya diperlukan dua buah dioda untuk menyearahkan tegangan keluaran trafo. Pada penyearah ini digunakan dua dioda untuk menyerahkan hasil keluaran dari trafo center tap. Gambar 4[9][10]. Menunjukkan rangkaian penyearah output 24 volt arus searah.

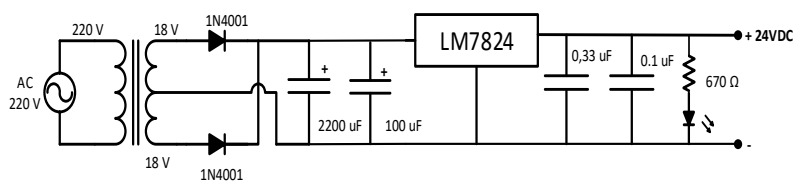

Gambar 4. Penyearah gelombang penuh satu fase dengan center tap

\subsection{Rangkaian Pengereman Plugging}

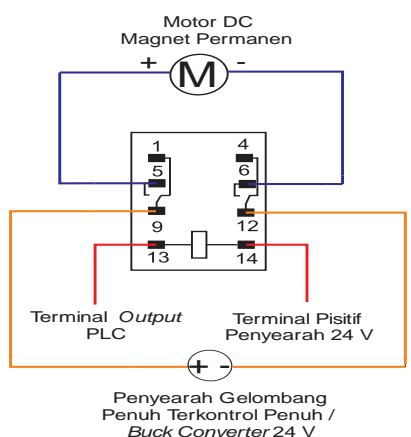

a.

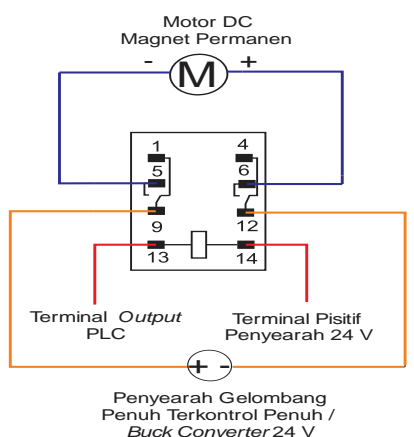

b.
Gambar 5. Rangkaian pengereman plugging

Gambar 5 (a) motor bergerak secara normal dimana output relay pin 5 dihubungkan dengan terminal positif motor dan pin 8 dihubungkan dengan terminal negatif motor. Dalam keadaan normal arus armatur adalah[11][12]:

$I=\frac{E_{5}-E_{0}}{R_{0}}$

Gambar 5 (b) pengereman plugging dimana pin output relay 5 dihubungkan dengan terminal negatif motor dan pin 12 dihubungkan dengan terminal positif motor. Dalam keadaan breaking arus armatur adalah[11]:

$I=\frac{E_{S}+E_{0}}{R}$

Keterangan:

$$
\begin{array}{ll}
\mathrm{I} & =\text { Arus Armatur }(\mathrm{A}) \\
\mathrm{Vt} & =\text { Tegangan Terminal }(\mathrm{V}) \\
\mathrm{E}_{0} & =\text { Tegangan Armatur }(\mathrm{V}) \\
\mathrm{R}_{0} & =\text { Hambatan Armatur }(\Omega) \\
\mathrm{R} & =\text { Hambatan pengereman }(\Omega)
\end{array}
$$

\subsection{Penentuan Motor Dan Berat Beban Yang Digunakan}

Sistem mekanika gerakan prototype overhead crane memerlukan sistem lock pada gear agar saat tak bertegangan motor tidak berubah posisi atau tergelincir. Prototype overhead crane mode hoist digerakan oleh motor arus searah tipe CSD80A1-A dengan spesifikasi sebagai berikut[13]:

Tabel 1. Spesifikasi motor arus searah

\begin{tabular}{lllll}
\hline Tipe & $\begin{array}{l}\text { Torsi } \\
\text { (N.m) }\end{array}$ & $\begin{array}{l}\text { Kecepatan } \\
(\mathbf{R p m})\end{array}$ & $\begin{array}{l}\mathrm{V}_{\text {rating }} \\
\text { (V) }\end{array}$ & $\begin{array}{l}\text { I Tanpa Beban } \\
(\mathbf{A})\end{array}$ \\
\hline CSD80A1-A & 3 & $\geq 90$ & 12 & $\leq 1,5$ \\
\hline
\end{tabular}

Pada Tabel 1. Menunjukkan spesifikasi motor arus searah yang akan digunakan pada Prototype Overhead Crane mode hoist, dengan parameter tersebut. 
Untuk mengetahui berat beban maksimal yang diangkat oleh motor dapat menggunakan persamaan (3).

Panjang jari-jari gear motor adalah $2.5 \mathrm{~cm}$, dan torsi pada Tabel 1. adalah $3 \mathrm{Nm}$, maka diperoleh :

$$
\begin{aligned}
& \tau=F \cdot R \\
& F=\frac{a N m}{0,025 \mathrm{~m}} \\
& \mathrm{~F}=120 \mathrm{~N}
\end{aligned}
$$

Keterangan:

$$
\begin{array}{ll}
\mathrm{T} & =\text { Torsi }(\mathrm{Nm}) \\
\mathrm{F} & =\text { Gaya }(\mathrm{N}) \\
\mathrm{R} & =\text { Panjang jari-jari gear motor }(\mathrm{m})
\end{array}
$$

Gaya beban yang diperoleh dari persamaan (3) adalah $120 \mathrm{~N}$

$$
\begin{aligned}
& \mathrm{F}=\mathrm{m} \cdot \mathrm{g} \\
& \mathrm{m}=\frac{\mathrm{F}}{\mathrm{g}} \\
& \mathrm{m}=\frac{120 \mathrm{~N}}{9,8 \mathrm{~m} / \mathrm{s} 2} \\
& \mathrm{~m}=12,24 \mathrm{Kg}
\end{aligned}
$$

Keterangan:

$$
\begin{array}{ll}
\mathrm{F} & =\text { Gaya }(\text { Newton }) \\
\mathrm{m} & =\text { massa }(\mathrm{Kg}) \\
\mathrm{g} & =\text { percepatan gravitasi bumi }\left(9,8 \mathrm{~m} / \mathrm{s}^{2}\right)
\end{array}
$$

Dari perhitungan pada persamaan (3) dan (4), maka dapat diketahui berat maksimum yang dapat diangkat motor arus searah CSD80A1-A adalah 12,24 Kg.

\section{Hasil dan Analisa}

\subsection{Pengujian Sumber Tegangan AC Satu Fase}

Pengujian yang pertama dilakukan adalah mengukur nilai sumber tegangan jala-jala PLN satu fase 220 volt yang diturunkan tegangannya menjadi 18 volt menggunakan trafo. Bentuk dan besarnya tegangan dapat dilihat pada Gambar 6 sebagai berikut:

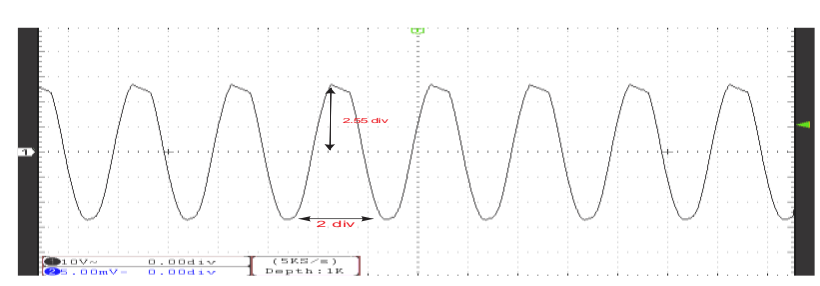

Gambar 6. Gelombang keluaran sumber tegangan AC satu fase

Trafo digunakan untuk mensuplai input dan output PLC. Pengukuran tegangan pada trafo menggunakan osiloskop.
Hasil pengukuran tegangan fasa - netral pada sumber 1 fasa menunjukkan tegangan puncak sebesar 2,55 div, maka dapat dihitung tegangan puncaknya sebesar:

$$
\mathrm{Vp}=2,55 \operatorname{div} \mathrm{x} 10 \mathrm{v} / \mathrm{div}=25.5 \text { volt }
$$

Maka tegangan rata-ratanya adalah:

$$
\begin{aligned}
& \text { Vrms }=V p / \sqrt{ } 2 \\
& \text { Vrms }=25.5 / \sqrt{ } 2=18.03 \text { Volt }
\end{aligned}
$$

Dengan menggunakan persamaan (5) dapat diperoleh nilai tegangan efektif yaitu sebesar 18.03 volt.

\subsection{Pengujian Sumber Tegangan Searah 24 Volt}

Pada pengujian ini, data diambil dari nilai keluaran tegangan searah pada rangkaian regulator tegangan IC LM7824 terhadap ground. Regulator tegangan ini digunakan sebagai suplai input dan output PLC[14].

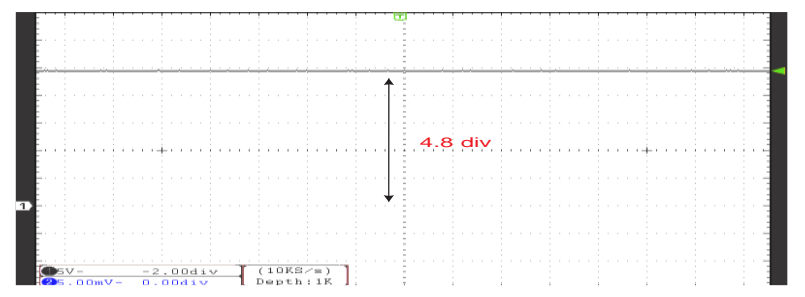

Gambar 7. Gelombang keluaran sumber tegangan searah 12 Volt

Gambar 7 menunjukkan besar tegangan keluaran regulator sebesar 4.8 div vertikal sehingga dengan perhitungan didapat nilai tegangan keluaran sesungguhnya sebagai berikut:

$$
V_{D C}=4.8 \text { div } x 5 \frac{V}{d i v}=24 \text { Volt }
$$

Nilai tegangan keluaran penyearah sudah sesuai yaitu bernilai $24 \mathrm{~V}$.

\subsection{Pengujian Program}

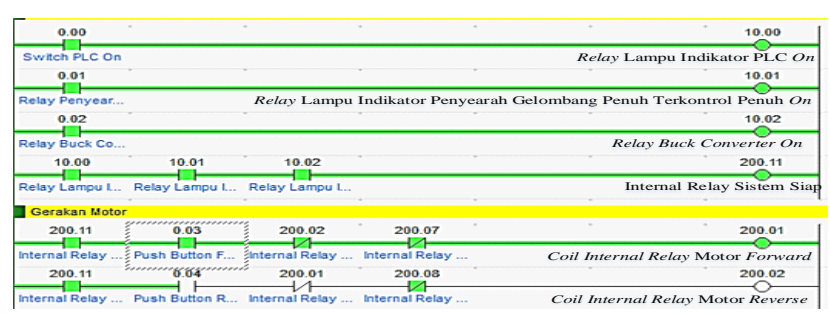

Gambar 8. Simulasi deteksi kegagalan penyearah gelombang penuh terkontrol penuh dan buck converter 
PadaGambar 8 terlihat ketika kontak penyearah gelombang penuh terkontrol penuh (0.01) dan buck converter (0.02) diaktifkan maka akan mengaktifkan coil relay lampu indikator penyearah gelombang penuh terkontrol penuh On (10.01) dan buck converter On (10.02), sehingga mengaktifkan kontak relay lampu indikator buck converter On (10.02).

Karena relay lampu indikator PLC On, penyearah gelombang penuh terkontrol penuh On, dan buck converter On sudah aktif sehingga mengaktifkan coil internal relay sistem siap (200.11). Alamat internal relay sistem menandakan bahwa prototype overhead crane siap dioperasikan. Terlihat ketika kontak push button forward (0.03) On ditandai dengan berubahnya warna kontak menjadi hijau, coil internal relay motor forward (200.01) On. Apabila salah satu syarat pengaktifan coil internal relay sistem siap tidak terpenuhi maka prototype overhead crane belum dapat dioperasikan.

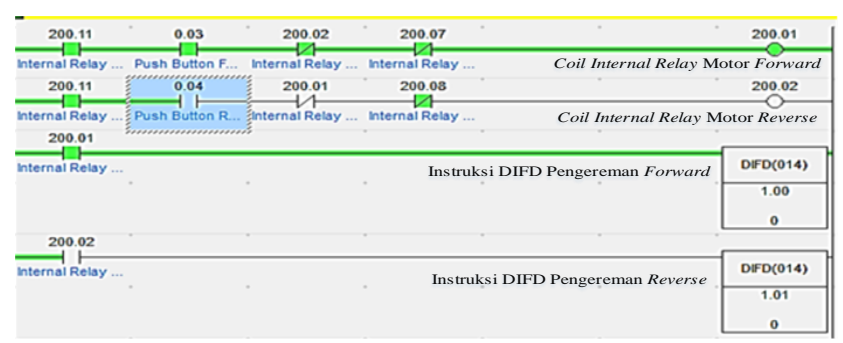

Gambar 9. keadaan ketika kontak push button forward On

Gambar 9 menunjukkan kontak kontak push button forward (0.03) sehingga menyebabkan coil internal relay motor forward aktif dan mengenergize instruksi DIFD (1.00), tetapi instruksi ini belum beroperasi sampai push button forward (0.03) kembali Off.

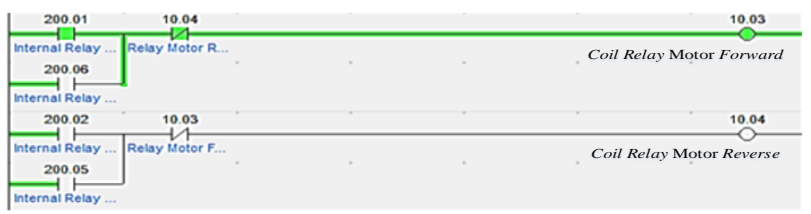

Gambar 10. keadaan ketika motor bergerak forward

Gambar 10 menunjukkan kondisi motor ketika bergerak forward. Hal ini ditandai dengan coil relay motor forward (10.03) aktif. Hal ini disebabkan karena kontak internal relay motor forward (200.01) dalam kondisi On. Hal ini menunjukkan bahwa mekanisme gerakan sudah bekerja dengan baik. Mekanisme kerja gerakan forward dan reverse adalah sama.

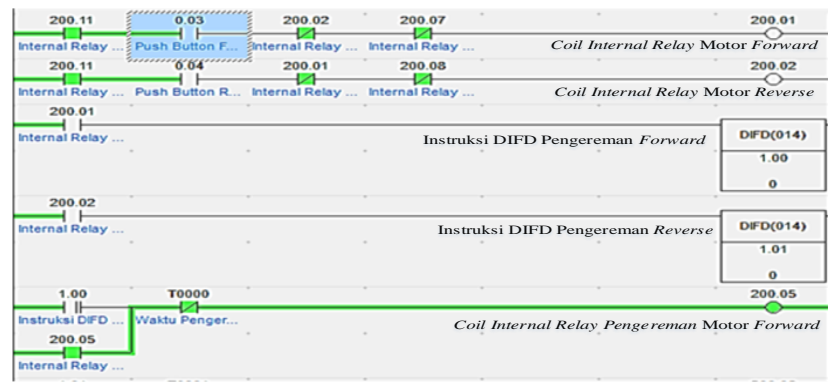

Gambar 11. keadaan ketika push button forward kembali Off

Gambar 11 menunjukkan sesaat setelah kontak push button forward kembali Off, dimana instruksi DIFD (1.00) tidak terenergize dan menjadi aktif. Hal ini ditandai dengan aktifnya coil internal relay pengereman motor forward (200.05).

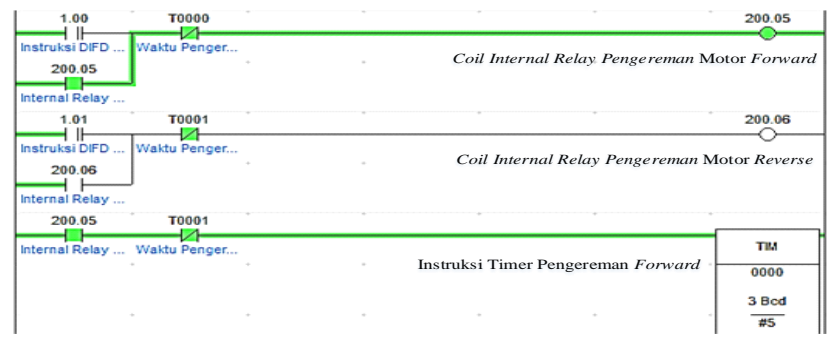

Gambar 12. Kondisi instruksi timer sebagai waktu pengereman

Gambar 12 terlihat bahwa instruksi timer forward (T0000) aktif ketika kontak internal relay pengereman motor forward aktif. Fungsi dari timer adalah pengatur waktu terjadinya pengereman. Pengereman pada PLC CJ1M dilakukan selama $5 \mathrm{BCD}$ atau 0.5 detik dimana nilai 1 BCD adalah 0.1 detik[15]. Hal ini menunjukkan bahwa mekanisme pengereman sudah bekerja dengan baik. Mekanisme pengereman motor forward dan reverse adalah sama.

\subsection{Pengujian Deteksi Kegagalan Penyearah Gelombang Penuh Terkontrol Penuh dan Buck Converter}

Pengujian relay ini dimaksudkan untuk memperoleh tegangan minimal relay dapat bekerja. Pengujian ini dilakukan dengan memberikan variasi suplai tegangan kepada relay dengan sumber dai penyearah gelombang penuh terkontrol penuh dan buck converter. Pengujian dilakukan dilakukan dalam keadaan relay LY2N tidak terhubung dengan PLC dan Motor.. 
Tabel 2. Tegangan On dan Off relay input penyearah gelomang penuh terkontrol penuh dan buck converter

\begin{tabular}{cccc}
\hline \multicolumn{2}{c}{ Tegangan On (V) } & \multicolumn{2}{c}{ Tegangan Off (V) } \\
$\begin{array}{c}\text { Penyearah } \\
\text { Gelombang } \\
\begin{array}{c}\text { Penuh } \\
\text { Terkontrol } \\
\text { Penuh }\end{array}\end{array}$ & $\begin{array}{c}\text { Penyearah } \\
\text { converter }\end{array}$ & $\begin{array}{c}\text { Gelombang Penuh } \\
\text { Terkontrol Penuh }\end{array}$ & converter \\
\hline 5,3 & & & \\
\hline
\end{tabular}

Berdasarkan Tabel 2 didapatkan bahwa Relay LY2N dapat bekerja dengan tegangan minimal sekitar 5,3 volt pada penyearah gelombang penuh terkontrol penuh dan 7,7 volt pada buck converter. Sedangkan tegangan off 3,3 volt pada penyearah gelombang penuh terkontrol penuh, dan 5,5 volt pada buck converter. Pada relay MY2N tidak dilakukan pengujian karena relay tersebut mendapat suplai yang tetap yaitu 24 volt dari penyearah[16].

\subsection{Pengujian Pengereman Plugging}

Tabel 3. data pengereman gerakan longitudinal tanpa beban

\begin{tabular}{ccc}
\hline $\begin{array}{c}\text { Tegangan Suplai } \\
\text { (V) }\end{array}$ & $\begin{array}{c}\text { Arus Pengereman } \\
\text { Forward (A) }\end{array}$ & $\begin{array}{c}\text { Arus Pengereman } \\
\text { Reverse (A) }\end{array}$ \\
\hline 6 & 2 & 2 \\
8 & 2,2 & 2,3 \\
10 & 2,5 & 2,7 \\
12 & 3 & 3 \\
\hline
\end{tabular}

Pada Tabel 3 terlihat bahwa semakin besar tegangan semakin besar pula arus. Arus pengereman longitudinal forward dan reverse memiliki perbedaan yang tidak signifikan. Hal ini menunjukkan kinerja motor ketika bergerak longitudinal dan reverse adalah sama. Dari Tabel 2 dapat dibuat grafik hubungan arus dan tegangan saat pengereman

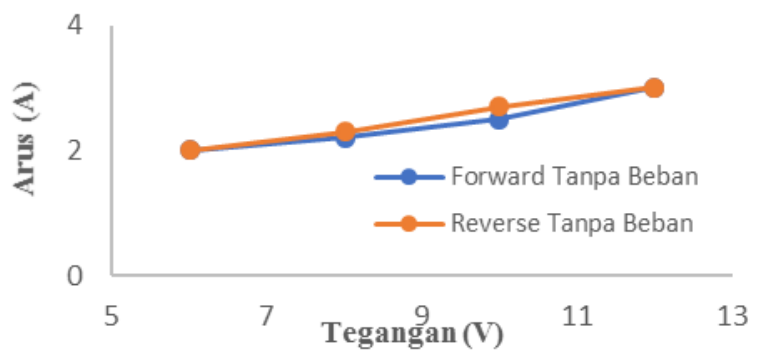

Gambar 13. Hubungan arus pengereman dan tegangan suplai longitudinal tanpa beban

Pada Gambar 13 grafik hubungan hubungan arus dan tegangan pengereman longitudinal tanpa beban dimana pada tegangan 6 volt arus pada gerakan forward adalah 2 ampere dan pada gerakan reverse adalah 2 ampere, sedangkan pada tegangan 8 volt arus pengereman forward adalah 2,2 ampere dan reverse adalah 2,3 ampere. Begitu pula pada tegangan 10 volt, arus pengereman forward adalah 2,5 ampere dan reverse adalah 2,7 ampere. Pada saat tegangan 12 volt nilai arus pengereman forward adalah 3 ampere dan reverse adalah 3 ampere. Sehingga dapat disimpulkan semakin besar tegangan pengereman maka semakin besar pula arus pengereman. Dari Tabel 3 dapat dihitung torsi pengereman dengan menggunakan persamaan 6[17].

$\tau=K_{E} \times I$

Keterangan:

$$
\begin{array}{ll}
\mathrm{Ea} & =\text { Tegangan Balik }(\mathrm{V}) \\
\mathrm{K}_{\mathrm{E}} & =\text { Konstanta Tegangan }(\mathrm{V} /(\text { radian} / \text { detik })) \\
I & =\text { Arus pengereman }(\mathrm{A})
\end{array}
$$

Nilai konstanta $\mathrm{K}_{\mathrm{E}}$ diperoleh dari tegangan balik dan kecepatan sudut motor. Dimana tegangan balik sebesar 11,019 Nm dan keceptan sudut sebesar 11,51 radian/detik, sehingga diperoleh konstantan $\mathrm{K}_{\mathrm{E}}$ :

$K_{E}=\frac{11,019}{11,51}$

$K_{E}=0,957$

Dengan substitusi persamaan 6 ke persamaan 7 diperoleh persamaan torsi pengereman motor arus searah magnet permanen :

$\tau=0,957 \times I$

Dengan substitusi arus pengereman ke persamaan 8 maka diperoleh torsi pengereman sebagai berikut.

Tabel 4. Hasil perhitungan torsi gerakan longitudinal tanpa beban

\begin{tabular}{ccc}
\hline Tegangan Suplai $(\mathrm{V})$ & $\begin{array}{c}\text { Torsi Pengereman } \\
\text { Forward }(\mathbf{N m})\end{array}$ & $\begin{array}{c}\text { Torsi Pengereman } \\
\text { Reverse }(\mathbf{N m})\end{array}$ \\
\hline 4 & 1,91 & 1,91 \\
6 & 2,1 & 2,2 \\
8 & 2,39 & 2,58 \\
9 & 2,87 & 2,87 \\
\hline
\end{tabular}

Berdasarkan Tabel 4 terlihat bahwa semakin besar nilai tegangan maka semakin besar pula torsi yang dihasilkan. Besar torsi pengereman ketika forward dan reverse tidak berbeda jauh, hal ini menandakan bahwa kinerja motor ketika pengereman forward dan reverse adalah sama.

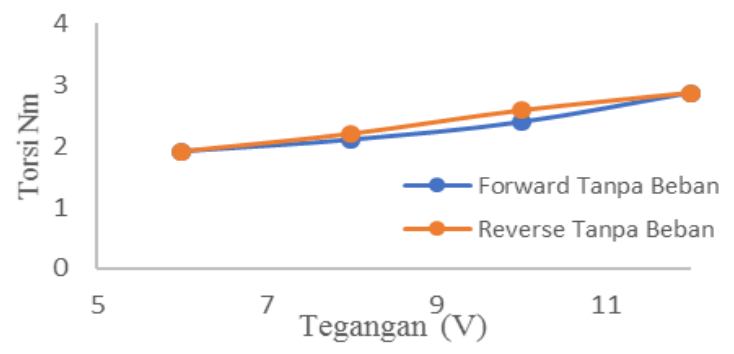

Gambar 14. Hubungan torsi pengereman dan tegangan suplai longitudinal tanpa beban 
Pada Gambar 14 grafik hubungan hubungan torsi pengereman dan tegangan suplai longitudinal tanpa beban dimana pada tegangan 6 volt torsi pada gerakan forward adalah 1,91 $\mathrm{Nm}$ dan pada gerakan reverse adalah 1,91 $\mathrm{Nm}$, sedangkan pada tegangan 8 volt torsi pengereman forward adalah $2,10 \mathrm{Nm}$ dan reverse adalah $2,20 \mathrm{Nm}$. Begitu pula pada tegangan 10 volt, torsi pengereman forward adalah 2,39 $\mathrm{Nm}$ dan reverse adalah 2,58 Nm. Pada saat tegangan 12 volt nilai torsi pengereman forward adalah 2,87 $\mathrm{Nm}$ dan reverse adalah 2,87 Nm. Sehingga dapat disimpulkan semakin besar tegangan pengereman maka semakin besar pula torsi pengereman. Pada Gambar 14 terlihat bahwa grafik ketika forward dan reverse berhimpit, hal ini menunjukkan kinerja motor ketika forward dan reverse adalah sama.

Tabel 5. data pengereman gerakan longitudinal beban $5 \mathrm{Kg}$

\begin{tabular}{ccc}
\hline $\begin{array}{c}\text { Tegangan Suplai } \\
\text { (V) }\end{array}$ & $\begin{array}{c}\text { Arus Pengereman } \\
\text { Forward (A) }\end{array}$ & $\begin{array}{c}\text { Arus Pengereman } \\
\text { Reverse (A) }\end{array}$ \\
\hline 4 & 2,2 & 2,5 \\
6 & 2,5 & 2,7 \\
8 & 2,7 & 2,7 \\
9 & 3,2 & 3,2 \\
\hline
\end{tabular}

Pada Tabel 5 terlihat bahwa semakin besar tegangan semakin besar pula arus. Arus pengereman longitudinal forward dan reverse memiliki perbedaan yang tidak signifikan. Hal ini menunjukkan kinerja motor ketika bergerak longitudinal forward dan reverse adalah sama.

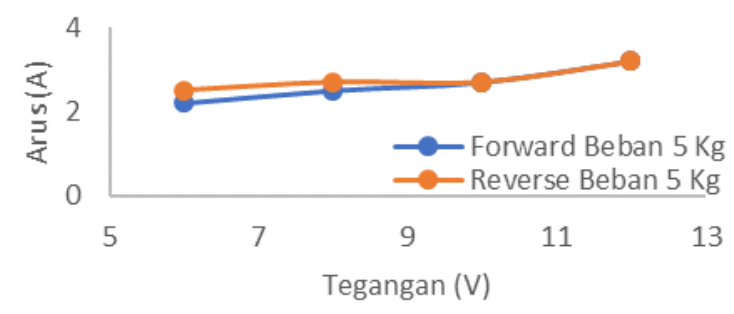

Gambar 15. Hubungan arus dan tegangan pengereman longitudinal beban $5 \mathrm{Kg}$

Pada Gambar 15 grafik hubungan hubungan arus dan tegangan pengereman longitudinal tanpa beban dimana pada tegangan 6 volt arus pada gerakan forward adalah 2,2 ampere dan pada gerakan reverse adalah 2,5 ampere, sedangkan pada tegangan 8 volt arus pengereman forward adalah 2,5 ampere dan reverse adalah 2,7 ampere. Begitu pula pada tegangan 10 volt, arus pengereman forward adalah 2,7 ampere dan reverse adalah 2,7 ampere. pada saat tegangan 12 volt nilai arus pengereman forward adalah 3,2 ampere dan reverse adalah 3,2 ampere. Sehingga dapat disimpulkan semakin besar tegangan pengereman maka semakin besar pula arus pengereman. Pada Gambar 15 terlihat bahwa grafik ketika forward dan reverse berhimpit, hal ini menunjukkan kinerja motor ketika forward dan reverse adalah sama.
Tabel 6. Hasil perhitungan torsi gerakan longitudinal beban $5 \mathrm{Kg}$

\begin{tabular}{ccc}
\hline $\begin{array}{c}\text { Tegangan } \\
\text { Suplai }(\mathrm{V})\end{array}$ & $\begin{array}{c}\text { Torsi Pengereman } \\
\text { Forward }(\mathrm{Nm})\end{array}$ & $\begin{array}{c}\text { Torsi Pengereman } \\
\text { Reverse }(\mathrm{Nm})\end{array}$ \\
\hline 6 & 2,10 & 2,39 \\
8 & 2,39 & 2,58 \\
10 & 2,58 & 2,58 \\
12 & 3,06 & 3,06 \\
\hline
\end{tabular}

Berdasarkan Tabel 6 terlihat bahwa semakin besar nilai tegangan maka semakin besar pula torsi yang dihasilkan. Besar torsi pengereman ketika forward dan reverse tidak berbeda jauh, hal ini menandakan bahwa kinerja motor ketika pengereman forward dan reverse adalah sama.

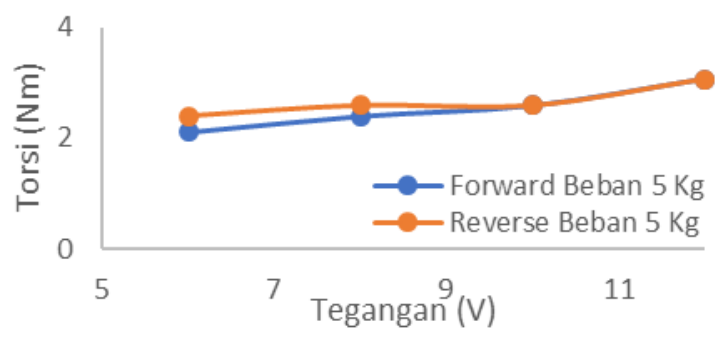

Gambar 16. Hubungan torsi dan tegangan pengereman longitudinal beban $5 \mathrm{Kg}$

Pada Gambar 16 grafik hubungan hubungan torsi dan tegangan pengereman longitudinal tanpa beban dimana pada tegangan 6 volt torsi pada gerakan forward adalah $2,10 \mathrm{Nm}$ dan pada gerakan reverse adalah $2,39 \mathrm{Nm}$, sedangkan pada tegangan 8 volt torsi pengereman forward adalah 2,39 $\mathrm{Nm}$ dan reverse adalah 2,58 Nm. Begitu pula pada tegangan 10 volt, torsi pengereman forward adalah 2,58 $\mathrm{Nm}$ dan reverse adalah 2,58 Nm. Pada saat tegangan 12 volt nilai torsi pengereman forward adalah 3,06 Nm dan reverse adalah 3,06 Nm. Sehingga dapat disimpulkan semakin besar tegangan pengereman maka semakin besar pula torsi pengereman. Pada Gambar 16 terlihat bahwa grafik ketika forward dan reverse berhimpit, hal ini menunjukkan kinerja motor ketika forward dan reverse adalah sama.

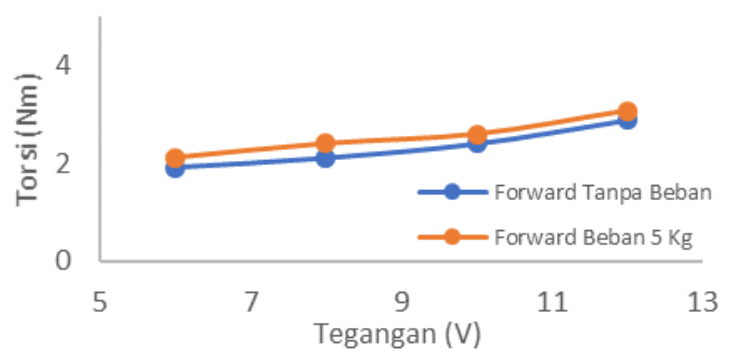

Gambar 17. Hubungan torsi pengereman longitudinal forward tanpa beban dan beban $5 \mathrm{Kg}$ 


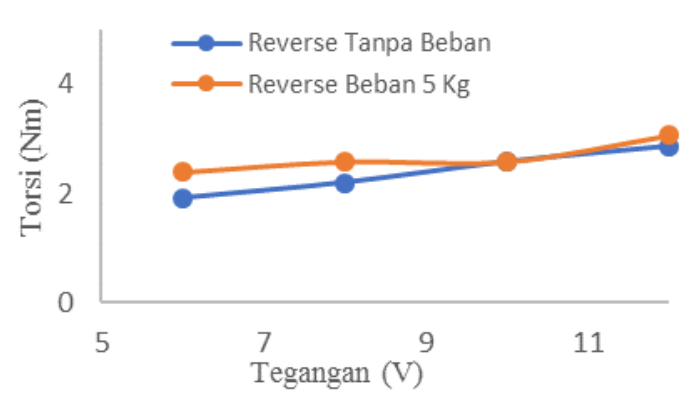

Gambar 18. Hubungan torsi pengereman longitudinal reverse tanpa beban dan beban $5 \mathrm{Kg}$

Berdasarkan Gambar 17 dan Gambar 18 didapatkan kesimpulan bahwa torsi pengereman ketika beban $5 \mathrm{Kg}$ lebih besar dibanding tanpa beban. Hal ini disebabkan karena pada saat berbeban motor membawa beban seberat $5 \mathrm{Kg}$, sehingga menyebabkan arus motor semakin besar oleh karena itu torsi juga semakin besar.

\section{Kesimpulan}

Programable Logic Controller (PLC) telah berhasil diimplementasikan sebagai gerakan motor arus searahpada prototype overhead crane. Diagram tangga dibuat sebagai program pengaturan dalam sistem PLC untuk mengatur koordinasi kerja gerakan motor dengan relay $24 \mathrm{~V}$ MY2N, limit switch, dan relay $12 \mathrm{~V}$ LY2N. PLC juga dapat mendeteksi kegagalan kerja penyearah gelombang penuh terkontrol penuh dan buck converter telah berhasil dibuat dibuktikan ketika salah satu atau keduanya dari penyearah gelombang penuh terkontrol penuh dan buck converter tidak bekerja (mengalami ganguan) prototype overhead crane tidak dapat beroperasi. Perancangan pengereman plugging pada motor telah berhasil dibuat dibuktikan ketika motor dalam keadaan steady state kemudian dilakukan pengereman maka motor akan berhenti seketika dengan waktu pengereman pada program 0,01 detik dalam keadaan tanpa beban dan beban $5 \mathrm{Kg}$. Saat pengereman plugging, semakin besar tegangan pengereman maka semakin besar pula arus pengereman, sehingga menyebabkan torsi pengereman semakin besar pula. Perancangan mekanika dan pengereman plugging motor arus searah pada prototype overhead crane berbasis plc dapat dikembangkan lagi menggunakan mikrokontroler sebagai pengganti PLC dan menggunakan pengereman dinamis dengan penentuan nilai hambatan pengereman yang tepat.

\section{Referensi}

[1] Ray Siddhartha Ph.D., Introduction To Material Handling, 1st ed. New Delhi: New Age International, 2008.

[2] N. Nugroho and S. Agustina, "Analisa Motor DC Sebagai Penggerak Mobil Listrik," Mikrotiga, vol. 2, no. 1, pp. 28-34, Jan. 2015.

[3] P. Tawakal, A. Nugroho, and M. Facta, "Penyearah Terkontrol Penggerak Motor Arus Searah Pada Purwarupa Konveyor," Transient, vol.5, no. 3, pp. 389394, Sep. 2016.

[4] I. Setiawan, Programmable Logic Controller. Yogyakarta: PENERBIT ANDI, 2005.

[5] H. N. Handoko and T. Sukmadi, "Pengendali Motor Induksi Tiga Fasa Menggunakan Programmable Logic Control (PLC) Untuk Pengolahan Kapuk," Transient, vol. 3, no. 1, pp. 29-36, Mar. 2014.

[6] R. P. Jaya, M. Facta, and T. Sukmadi, "Perancangan Sistem Proteksi Arus Dan Temperatur Lebih Menggunakan Programmable Logic Control ( Plc ) Pada Mesin Pengekstraksi Biji Kapuk," Transient, vol. 4, no. 2, pp. 419-426, Jun. 2015.

[7] M. F. Reza Fakhrizal, Tedjo Sukmadi, "Aplikasi Programmable Logic Controller ( PLC ) Pada Pengasutan Dan Proteksi Bintang (Y) - Segitiga $(\Delta)$ Motor Iinduksi Tiga Fasa," vol. 3, pp. 344-356, Jun. 2015.

[8] A. A. Putri, M. Facta, and T. Sukmadi, "(Studi Kasus : Monitoring Kecepatan Dan Safety Device Konveyor Pada Mesin Pengekstraksi Biji Kapuk)," Transient, vol. 4, no. 1, pp. 169-184, Mar. 2015.

[9] M. H. Rashid, Power Electronic, 3rd ed. Florida: Elsilver, 2001.

[10] H. F. A. Prabowo, M. Facta, and A. Nugroho, "Analisis Resonant Trafo Step Up dengan Penyearah CT dan Jembatan Penuh," Transient, vol. 4, no. 3, pp. 542-549, Mar. 2015.

[11] T. Wildi, Electrical Machines, Drives, and Power System 5th Edition, 5th ed. Ohio: Pretice Hall, 2002.

[12] Genereal Purpose Relay MY, OMRON, North Geelong, JPN, 2008.

[13] Single Phase 12V Motorized Opener, L. Ningbo, Zheijang, CHN, 2012

[14] LM78XX Series Voltage Regulators, T.Component, Texas, USA, 1995.

[15] SYSMAC CQM1 Operation Manual, Omron., North Geelong, JPN, 2000.

[16] Genereal Purpose Relay LY, OMRON, North Geelong, JPN, 2008.

[17] T. K. J. Edward Carryer, Matthew Ohline, Introduction to Mechatronic Design, 1st ed. Berkeley: Prentice Hall, 2003. 